\title{
Virtualization of information as the direction of development of accounting support systems. Empirical evidence from Poland
}

\author{
Kinga Bauer $^{1}$, Michał Baran ${ }^{2}$ \\ ${ }^{1}$ Faculty of Management, Cracow University of Economics, ul. Rakowicka 27, 31-510 Cracow \\ ${ }^{2}$ Faculty of Management and Social Communication, Jagiellonian Universitty in Cracow, ul. Łojasiewicza 4, 30-348 Cracow \\ *Corresponding author E-mail: kinga.bauer@uek.krakow.pl
}

\begin{abstract}
A significant trend observed recently in shaping the communication condition between economic entities, and the authorities is the growing virtualization of information circulation. The aim of this article is to examine the attitudes and expectations of specialists (employees of accounting offices) towards the process. Opinions of the specialists and accounting community members were collected as part of a survey, in which the respondents came from the southern Polish territory. This location was chosen due to a particularly high rate of change to the location, which in turn made the respondents more sensitive to the issue. 114 interviews had been collected, which were then subjected to statistical analysis. The outcome, in the most general terms, indicates a generally positive attitude of the respondents towards the occurring phenomenon.
\end{abstract}

Keywords: Accounting; Bookkeeping; Information Management; Information Science; Virtualization.

\section{Introduction}

Economies of individual countries and the global economy are undergoing continuous changes. Accounting is invariably the main source of information about the financial condition and operational risks of a company. The informational role of accounting is emphasized in numerous scientific studies, although increasingly, financial reporting as a source of information for investors, management and other stakeholders is also criticized (eg. Alford, Jones, Leftwich \& Zmijewski 1993, Bushman \& Smith 2001, Chen, Chen \& Su 2001, Parsons 2003, Leuz, \& Wüstemann 2003, Bushman \& Piotroski 2006). However, the environment has also an impact on accounting. Not only on an attempt to standardize the rules regarding records of each transaction (Krasodomska 2010, Gierusz 2015), but also on the way data is collected, presented, archived and transmitted (e.g. Gos 2008, Micherda, Świetla 2014).

The changes taking place in recent years in terms of technology and communication of information are so radical that they can even be called a revolution. The most important thing, however, is that what has changed the most is the rate of change (Surdykowska, 1999, p. 19). The increasing pace of changes forces organizations to constantly improve the efficiency of information transfer. In the wake of this, an increasingly widespread use of the Internet follows, which can also be called a revolutionary change (Tadeusiewicz 2002 p. 18). Internet usage is associated with the desire to transmit information in real time. According to K. Kelly (1999, p. 18) ,The game in the network economy will be to find the overlooked small and figure out the best way to have them embrace the swarm."
Despite the increasingly widespread use of information systems in virtual organizations, scientific studies highlight the need for their further development for accounting purposes. Due to a problem such as the lack of applicable, distributed, and efficient accounting schemes, attempts to create specific solutions that would be perfect solutions for accounting, including accounting models for virtual organizations, are made (Buthelezi, Adigun, Ekabua, \& Iyilade 2008, Göhner, Waldburger, Gubler, Rodosek, \& Stiller 2009, Jiang, Novales, Mathieu, Casson, Rogers, \& Gordon 2011). Organizations are increasingly forced to transfer accounting information electronically, not only within the organization but also beyond. They take such actions voluntarily as well, in order to improve the efficiency of information flow. In light of the foregoing, it is assumed that virtualization of the financial information flow is favorable, and the usage of information derived from accounting will be more efficient and thus contribute to the development of enterprises.

The purpose of this article is to identify and analyze current development trends in accounting information systems, as a kind of catalyst for change as flow of information coming from accounting.

In connection with the role of virtualization in increasing the efficiency of business operations, the main objective of this paper is to answer the following questions:

- Perceptions of changes taking place in the way accounting information is circulated?

- What are further expectations for utilizing the possibilities offered by the Internet?

Both the mandatory and voluntary aspect to the issue at question will be examined.

Empirical studies were carried out in 2015 in Poland on a group of specialists in the field of accounting. Choosing Poland as a coun- 
try in which the study was conducted is intentional, and it us due to a relatively short period of time in which information systems in accounting are used. Thus, the pace of change in recent years has been faster than in countries with a longer tradition of use of IT tools in accounting, which allows to examine the phenomenon in greater detail.

The aim of the paper has come about during literature review and the authors' previous studies.

\section{The information on book-keeping in the context of the evolution of conditioning of its use}

In the modern world in the countries that achieved a high civilization level of development, there prevails the consensus that at present we live in the era of information. The information store became the key factor that facilitates the arrival at a commercial success which is responsible for the very sense of embarking upon economic activities. As a result, many companies resign from individually accomplishing the production of goods and concentrate on activities that are of coordination and creative nature and are ever more frequently undertaken in the virtual reality (Sierotowicz 2013). This trend is universally observed and it, to a lesser or larger extent, influences all forms of activities of economic entities. The ICT innovative solutions introduced by the market leaders that at first seemed to be only the augury of the new possibilities were soon becoming a binding standard which effectively modified the rules along which the market competition was conducted (Dziekoński 2011). This also gradually forces the discussed entities to implement certain adjustment reactions even in so conservative sphere of activities of any organization as the making of the book-keeping documentation in the company.

In the traditional approach to the information, there are emphasized the key parameters of the latter. Among them, there are such as: topicality, clearness, solidity and verifiability of the source from which the information derives. Likewise, the parameters include precision, objectivism, reliability, completeness (Baran 2008). It is worth noting that these features may negatively influence one another, thereby limiting the chance of arriving simultaneously at an optimum level in all the listed dimensions. What particularly comes into play at that point is the topicality of the information viewed in the context of the expected broad and exhaustive scope of knowledge that is being supplied. There also obviously comes into play the threat caused by collecting excessive proportion of data, which may reduce the possibility of their effective processing. It is a regular thing that the larger is the pressure on the faster supply of the needed data the greater is the difficulty in seeing to it that they be complete and reliable. The costs of obtaining the information appear to be an additional problem. $\mathrm{We}$, therefore, face the dilemma that is known in management: which dimension should be optimised. Should it be the price, the quality or perhaps the time of obtaining the data? On the other hand, it must be emphasized that in case of so specific sphere as that of book-keeping, the selection of priorities differs from that encountered in other areas (Rokita et al. 2012). The point is that usually any information whose obtaining is ordered by the managers is expected to serve for satisfying the internal needs of organization. It is expected to be a support in the decision-taking process. Yet - within the frame of accomplishing the book-keeping function - the equally important and in some situations the most important, goal for which the information serves is the supply of data requested by the external entities that exercise commanding power. In addition, this is the sphere that is subjected to strict legal regulations. Thus at the level of managing staff the dilemma, whether it is payable to document certain transactions ceases to appear. What is at the outmost left is the question, whether on the basis of what we already dispose of (due to what is obligatorily required) there is any possibility of learning something that might be of any use (Lipińska 2012).
As it has been mentioned, the performing of the function of the company's book-keepers requires their submission to the line determined by the provisions of law. This is visible both with regard to the scope as well as to the order, form or, finally, the necessity to submit to the requirements of work arising from the strictly defined periods of time. Obviously, there is still left certain scope of freedom in analysing the processed stores in accordance with the expectations of the managing staff, suitably to their position occupied in the hierarchy, the challenges that come into play, etc. As in any other case thus also in this case it is possible - in order to satisfy companies internal needs - to make additional specifications characterized by a freely selected level of aggregating. It is also possible to observe the dynamics of processes that follow and to resort to the reports of alternative indexes (Bauer 2009). However, these are always the external expectations of the environment that determine the fundamental assumptions of the mode of creating the book-keeping documentation and, on this occasion, specifying the minimal boundary conditions of organizing work within the discussed scope.

In the course of time, the IT technology performed a servicerendering role in the carrying out of the tasks assigned to those who did the book-keeping business. The solutions that followed one after the other turned out to be a convenient, willingly applied, although eventually not necessary tools to do the work. All the duties could still be the performer also in a traditional way. Obviously the pressure of the environment on the accelerating certain processes, reduction of burdens and optimising the costs of activities resulted in the universal tendency to reach for the modern information systems. However, that was still the question of free choice of the interested companies (Lasak 2009). Yet the mostrecent trends, observable at present, show that the situation has changed. The technological progress began to force the discussed entities to reach for certain solutions as those that are obligatorily applicable (Okoń-Horodyńska et al. 2013). What comes into play at this point is the question of virtualization of the circulation of the book-keeping documents and the question of applying the solutions that integrate an individual entity with its administrative environment and the providers or customers. This process gradually blurs the outlines of borders that previously strictly separated the respective organizations, and it creates out of them a complex net of collaborating and interrelated elements (Strojny et al. 2005). It is already now that the provisions of the law in force require that, in specified cases, the selected documents should be transmitted exclusively by electronics way. This forces those companies that fulfill the specified criteria to undertake the adjustment actions. The latter include the purchase of modern technological devices and employing the appropriately schooled staff. The question that appears is the following: is it the phenomenon one can escape from and - what is perhaps more important - is it worth escaping from? The awareness of the discussed entities of the outlined problem, their attitudes and opinion toward and on it make up a precious source of knowledge on how the discussed process follows and what may still be expected therefore (Budzanowska-Drzewiecka 2012).

\section{The recent evolution of accounting infor- mation systems in Poland}

Choosing Poland as a case for literature study and empirical research is intentional. There were profound political changes in Poland in 1989 that have affected changes to other areas too, such as changes to the approach to accounting and technological changes. According to E. Urbanowska-Sojkin, P. Banaszyk (2009, p. 339) "it can be assumed that the evolution of Polish companies has already completed the transition period, which conformed them to the modern business world." Currently, Poland is at a similar level of technological development as other developed countries, but the pace of change that took place in the last 25 years had been incomparably higher. These changes also required 
training new staff to enable them to meet challenges posed by life in the technological era.

Research carried out at the beginning of the twenty-first century on a group of small companies showed that only half of them had used computers in their business, and about $1 / 3$ had access to the Internet. The lack of economic knowledge, including accounting and payroll, was one of the main reasons for which companies outsourced financial and accounting services to accounting offices. Virtual bookkeeping is one of the areas in which virtual outsourcing has developed the fastest. Accountancy offices employ specialists and have the necessary software for bookkeeping; they provide accounting services to entities with the use of computer systems and the Internet. A virtual outsourcing client may electronically, i.e. through the Internet, provide the outsourcer the necessary data about business operations (Dziembek, Stępniak 2003).

The results of subsequent studies conducted by M. Matejun (2010) also point to the fact that for companies in the SME sector, a particularly popular solution is to outsource accounting and tax consulting, under which small and medium-sized enterprises benefit from constant outsourcing provided by authorized professionals referred to as accounting offices or offices of tax consulting offices. Thus, the risk of aging technology, incurring additional costs due to investing in accounting information systems, is transferred to an accounting office. According to surveyed employees of state tax offices, one of the main advantages is the ease of access to accounting records. In addition, according to the respondents, companies using accounting office's grow faster than those that do accounting in-house.

Research of I. Chomiak-Orsa (2007) on the use of modern technologies in controlling processes indicates that the implementation of integrated management systems is a major investment and organizational effort for businesses. A relatively low awareness among employees of companies that implement the systems deepened the difficulties associated with their implementation. In most businesses, distributed systems for accounting, payroll and fragmentary support for cost and financial calculations are utilized. These systems often come from different manufacturers, so compatibility is hampered.

Chojnacka (2007) analyzed the circulation of accounting documents from the perspective of operational management. As a result of - using the case study method - the study, she found that the use of modern information technology in accounting improves document circulation in an enterprise, reduces employee work time and provides greater opportunities for the management to control costs. In her studies the author has included the circulation of accounting documents within individual business units. In her view, modern information technologies (including computer networks and electronic document management systems) are used more often, in order to improve the organization of accounting documents circulation in an enterprise. There is a clear move away from paper to electronic documents.

In turn, the results of the survey conducted by K. SzymczykMadej (2014) in 2005 and 2014 indicate that the functioning of information systems in enterprises in Poland has not changed significantly. The author of the study believes that improvement has been made in accounting systems areas which are directly related to the development and use of information technology.

The results of empirical research conducted by K. Swietla (2014) clearly shows that in the case of outsourcing accounting services, there is currently a trend in Poland to search for on-line accounting services. At the same time, traditional accounting offices are also subject to evolution resulting from the needs reported by customers. Increasingly, they offer remote data transmission and access to their systems on-line.

In summary, according to previous studies, there is a clearly noticeable shift in Poland towards virtualization of the financial information flow. In the opinion of theorists and practitioners, these changes are beneficial for organizations. Virtualization of the information flow can affect the flow of information inside an en- terprise or serve as a means to improve communication with other entities.

Communication method inside a company is a matter of voluntary choice, but electronic communication with the authorities may be mandatory. The aim of further research is to determine whether virtualization applies not only to mandatory areas but also to voluntary areas, and whether, in the view of accounting professionals, it is a positive phenomenon which should develop in the future.

\section{Reception and expectations of the virtual- ization of accounting information circula- tion: the results of empirical research}

An assessment of solutions applied to change the accounting information flow and expectations regarding the increased use of the possibilities offered by the Internet are presented in the study. The study was conducted in the first half of 2015 , on a group of specialists from the southern region of Poland, employed in accounting and tax offices. It is an occupational group that actively participates in the creation and transmission of accounting information, at the same time has the knowledge and professional experience in the study area.

The survey form included 14 questions, mostly closed-ended. Respondents filled out the forms independently, if necessary with the help of assistants trained on the study area.

114 sets of answers to the survey questions were obtained as a result of the study. The sample size can be regarded as satisfactory, since the number of specialists who could have been taken into consideration in the study - is limited.

The statistical analysis of selected results of the survey is presented below. It includes an analysis of qualitative variables - based on number of answers given to particular questions by the respondents. In order to simplify the reception and increase the readability of the test results, the obtained values were converted and presented in percentage terms.

The first issue examined was the use of electronic communication between accounting and government offices on behalf of their clients. The survey question was: "In contact with the authorities on behalf of clients, do you use the option of communicating electronically?" Taken into account were: electronic correspondence, accounts documents with tax offices, accounts documents with the social security offices, as well as any other types of electronic contacts. One of the six possible answers were provided each time: "always", "often", "sometimes", "rarely", "never" and "do not know". 'I do not know' appeared only in the case of other types of electronic contacts - but it constitutes nearly $85 \%$. A summary of responses to question 1 is shown in Fig. 1.

The collected results lead to the conclusion that, when it comes to the exchange of electronic correspondence, the answer "often" clearly dominates - it constitutes $50 \%$ of responses. The distribution of answers is clearly shifted towards high frequency of contacts. In the case of official reporting documents for the tax offices, there is a clear shift towards the answer "always", it constitutes $36 \%$ of responses. It is worth mentioning that the total share of answers "always" or "often" is almost $70 \%$, which means that electronic correspondence with the tax office is already very popular. The results are even better for accounts balance of social insurance where "always" constitutes $39 \%$ of answers and an additional $32 \%$ of respondents declare "frequent" electronic contacts with Social Security Office. What is important, a low percentage of respondents declare refraining from (answer "never") or occasional use of (the answer "rarely") electronic form of contact with the authorities.

The total percentage of "always" or "often" answers is in all cases significant (not counting other types of electronic contacts) (Table $1)$. 


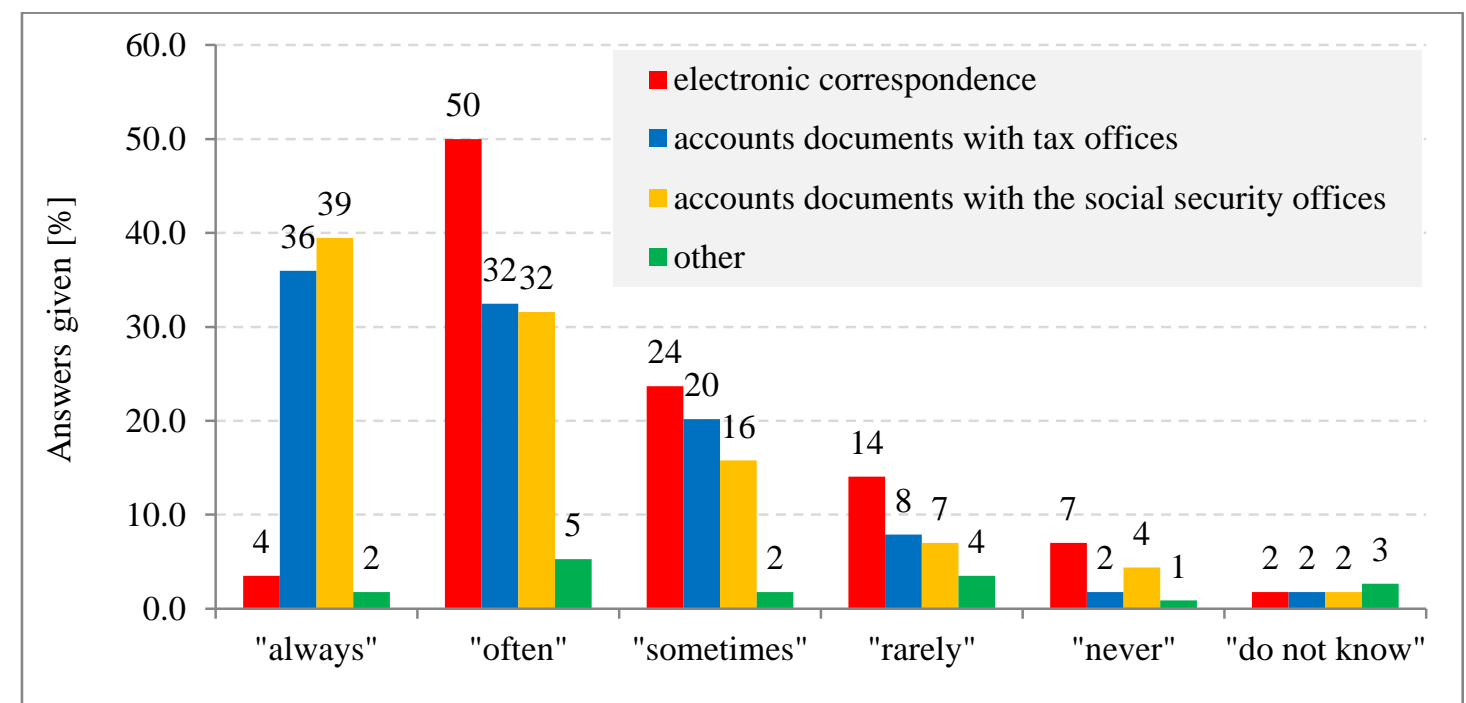

Fig. 1: Distribution of Answers to the Question: "In Contact with the Authorities on Behalf of Clients, Do You Use the Option of Communicating Electronically?" Source: Own Study

Table 1: Percentage Summary of "Always" or "often" Answers to the Question about Frequency of Use of Electronic Contact with Government Offices.

\begin{tabular}{llcc}
\hline Type of contact & $\begin{array}{l}\text { Answers "always" and } \\
\text { "often" [\%] }\end{array}$ & $\begin{array}{l}\text { Maximum error for answers } \\
\text { "always" and "often" [\%] }\end{array}$ & $\begin{array}{l}\text { Confidence interval (at confidence level of } \\
0.95) \\
\text { Lower limit [\%] }\end{array}$ \\
\hline $\begin{array}{lll}\text { Electronic correspondence } \\
\text { Account settlements with the tax office }\end{array}$ & 53.5 & 9.2 & 64.4 \\
Account settlements with social securi- & 71.1 & 8.5 & 59.9 \\
ty & & 8.3 & 62.7 \\
\hline
\end{tabular}

Source: own study

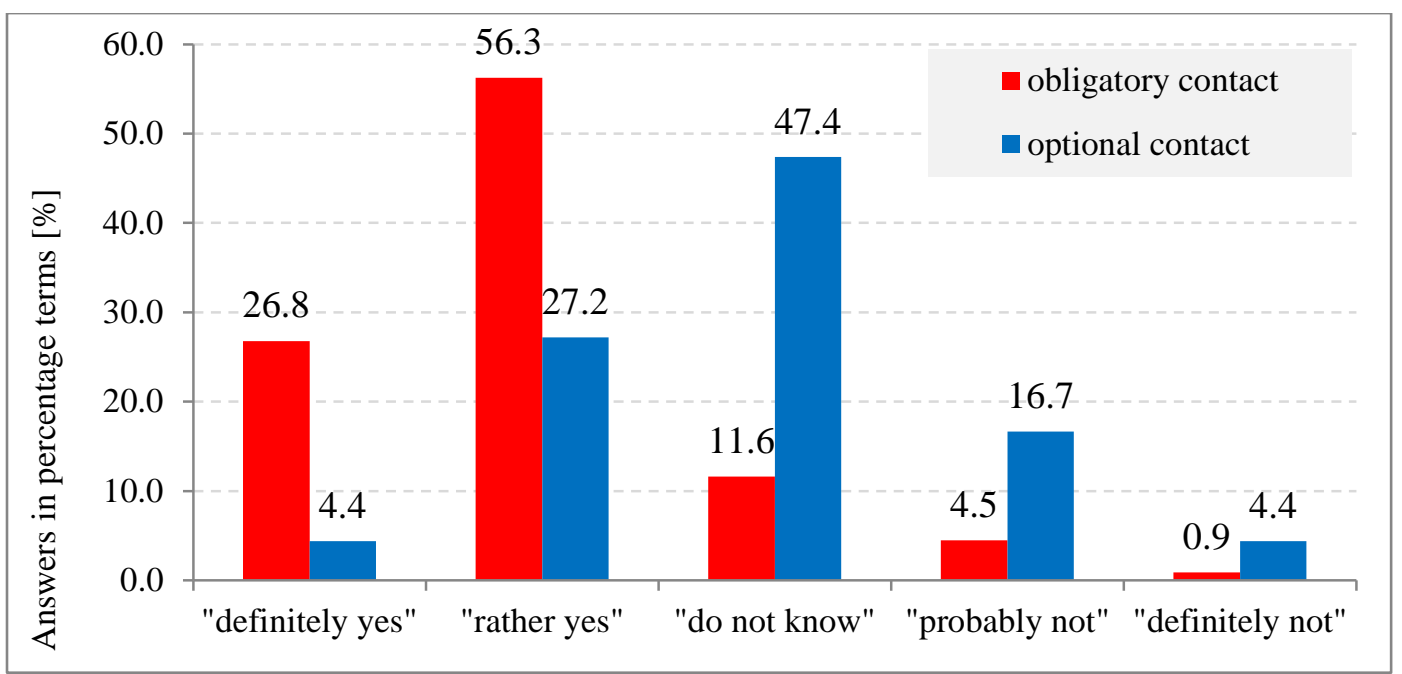

Fig. 2: Distribution of Answers to the Question: "In the Next 2 Years, Do You Expect Further Areas of Contact of Accounting Offices with the Authorities to Be Performed Electronically? Source: Own Study.

Percentage estimation errors of answers "always" or "often" - in all three cases - are significant from $8.3 \%$ to as much as $9.2 \%$, which makes it somewhat difficult to transfer the results from the sample group onto the entire population. This is due to the size of the study sample, selected from a relatively narrow circle of specialists. However, even if the lower limits of the confidence intervals for the answer percentages are accepted (based on a very high 95-percent confidence level) as the most probable - it can definitely be assumed that the virtualization of information is accepted and willingly used by the respondents.

The second question ("In the next 2 years, do you expect further areas of contact of accounting offices with the authorities to be performed electronically?") addressed the issue of assessing the possibility of expanding the scope of electronic communication with the authorities, in the near future. This issue was tested separately, in the field of mandatory and optional activities. Possible answers were "definitely yes", "rather yes" or "do not know", "probably not", and "definitely not". Based on the responses, a conclusion can be made that, when it comes to obligatory contacts, the vast majority of respondents expect a continuation of the studied phenomenon (almost $27 \%$ of respondents answered "definitely yes" and 56\% indicated "rather yes", table 2).

Completely different results were acquired in the case of the possibility of continuing optional electronic contacts with the authorities. As many as $47 \%$ of the respondents has no opinion on this matter or does not foresee changes. Only slightly more than $4 \%$ strongly believe (answer "definitely yes") that further areas of contact of accounting offices with the authorities will be covered by electronic exchange of information, while $27 \%$ believe that such a situation will probably take place.

The third question touched on the issue of benefits of (from the perspective of accounting offices) broadening the scope of virtualization of information circulation in contact with government offices. The answer to this question was supposed to show the real 
improvements in business operations. The scale of possible answers was the same as in the previous question. The distinction between mandatory and optional spheres was also applied. In the first case, $40 \%$ of respondents indicated that this phenomenon is definitely beneficial, $46 \%$ - it is rather favorable (only $2 \%$ of respondents replied "definitely not") (Fig. 3).

In the sphere of voluntary contacts, an even higher assessment of potential benefits dominated the responses, as indicated by $50 \%$ of "definitely yes", $38 \%$ of "rather yes" and zero of "definitely not". Compared to the previous question, the distribution of answers for mandatory and voluntary contacts are highly similar.

A thesis can be made that in general, accounting offices would like to make even greater use of contacts with the authorities, and hope that this will soon happen, at least in the obligatory sphere. This observation is also confirmed in Table 2, which summarizes the confidence intervals for "positive" responses (answer: "definitely yes" and "rather yes").
An analysis of responses to the fourth question ("Do you think that regulations forcing a partial communication with the authorities in electronic form are beneficial for the clients of your office?") allowed to assess subjective benefits for clients of accounting offices, which were the result of broadening the scope of virtualization of the information flow in contacts with the authorities. There were six answer possibilities: "definitely yes", rather yes", "yes and no", "probably not", "definitely not" and "do not know". In this case, no distinction between obligatory and optional spheres was made, focusing only on activities which were mandated by the evolving laws. Once again positive assessments dominated (28\% "definitely yes" and $46 \%$ "rather yes") but at the same time $20 \%$ of respondents chose the option "yes and no". However, the total share of "rather not" or "definitely not" responses was just below 3\%, remaining within the limit of statistical error (Fig. 4).

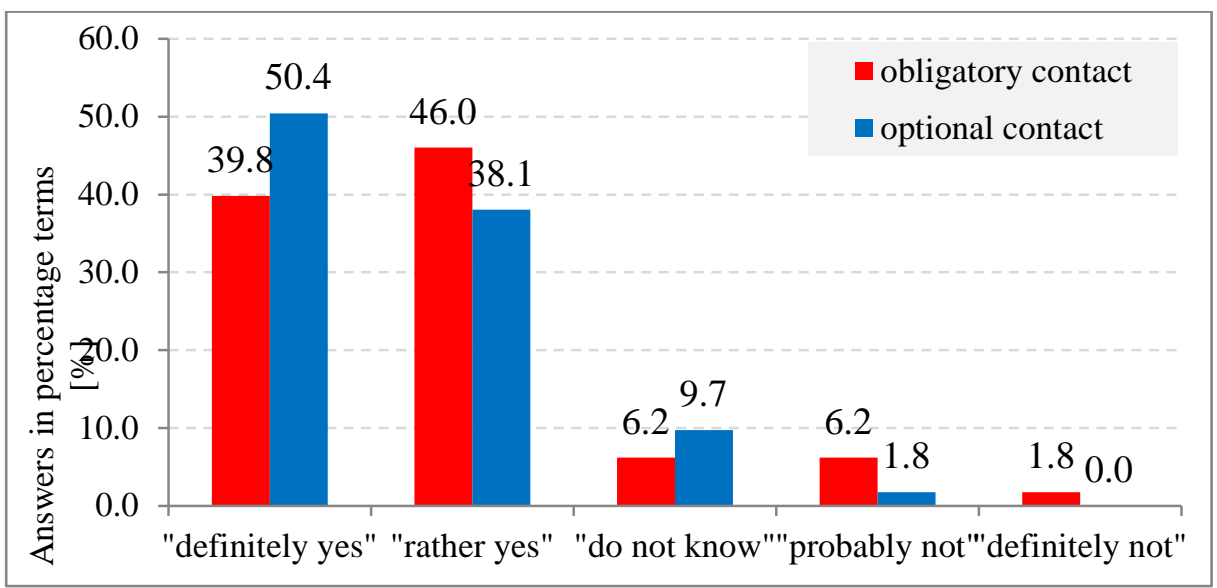

Fig. 3: Distribution of Answers to the Question "In Your Opinion, Is Gradually Broadening the Scope of Electronic Communication between Accounting Offices and Government Offices a Positive Phenomenon which Facilitates Your Business Activities?” Source: Own Study

Table 2: Summary in Percentage Terms of "Definitely Yes" and "Rather Yes" to Questions about the Expected Broadening of Areas of Electronic Contact between Accountancy Offices and Government Offices and Benefits of Gradual Broadening of the Scope of Electronic Communication between Accounting Offices and Government Offices.

\begin{tabular}{|c|c|c|c|c|c|}
\hline Question & $\begin{array}{l}\text { Type of contact with } \\
\text { government offices }\end{array}$ & $\begin{array}{l}\text { Answers } \\
\text { "definitely yes" and } \\
\text { "rather yes" [\%] }\end{array}$ & $\begin{array}{l}\text { Maximum error for } \\
\text { answers "definitely } \\
\text { yes" and "rather yes" } \\
{[\%]}\end{array}$ & $\begin{array}{l}\text { Confidence i } \\
\text { level of } 0.95 \text { ) } \\
\text { Lower limit } \\
{[\%]}\end{array}$ & $\begin{array}{l}\text { 1 (at confidence } \\
\text { Upper limit } \\
{[\%]}\end{array}$ \\
\hline $\begin{array}{l}\text { Expected broadening of areas } \\
\text { of electronic contact between }\end{array}$ & obligatory & 83.0 & 6.9 & 76.1 & 89.9 \\
\hline $\begin{array}{l}\text { accountancy offices and gov- } \\
\text { ernment offices }\end{array}$ & optional & 31.6 & 8.5 & 23.0 & 40.1 \\
\hline $\begin{array}{l}\text { Benefits of gradual broadening } \\
\text { of the scope of electronic com- }\end{array}$ & obligatory & 85.8 & 6.4 & 79.4 & 92.2 \\
\hline $\begin{array}{l}\text { munication between accounting } \\
\text { offices and government offices }\end{array}$ & optional & 88.5 & 5.9 & 82.6 & 94.4 \\
\hline
\end{tabular}

Source: own study

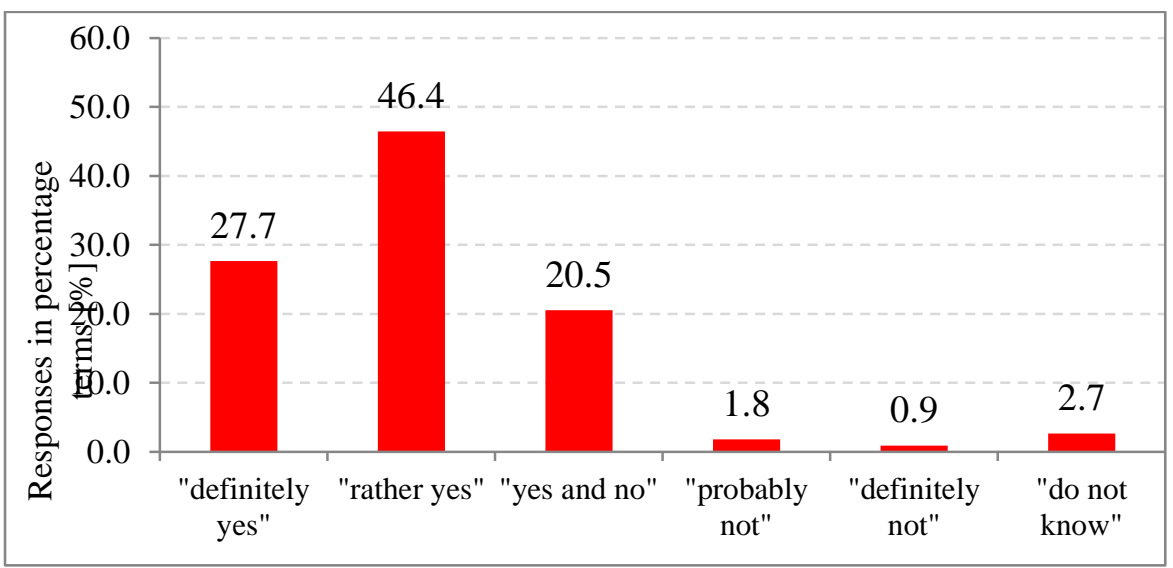

Fig. 4: Distribution of Answers to the Question: "Do You Think that Regulations Forcing a Partial Communication with the Authorities in Electronic form are Beneficial for Clients of Your Office?" Source: Own Study. 
The maximum error of estimating the percentage of positive responses is $8 \%$, which means that the percentage of "definitely yes" and "rather yes" responses in the total population, with a 95percent probability, will fall in the range of $66.1 \%$ to $82.1 \%$ making it significant even under the most unfavorable conditions. This means that, in the opinion of respondents legal regulations to force a partial communication with the authorities in electronic form are in most cases beneficial for the clients of accounting offices.

The purpose of the fifth question ("Is the progressive extension of the scope of electronic communication between accounting offices and clients a beneficial phenomenon from your perspective, facilitating the running of your business?") was to assess the benefits that stem from broadening the scope of virtualization of the information flow between accounting offices and their clients. It was decided that this type of phenomenon also occurs as a consequence of related changes initiated by legislation in the sphere of contacts with the authorities. It was assumed that accounting offices using information stored in a particular format and electronic version have an incentive to persuade their customers to use compatible solutions, thereby promoting some solutions. The range of possible answers was the same as in the previous question. $78 \%$ of accounting office's representatives found that this process facilitates business activities (Fig. 5).

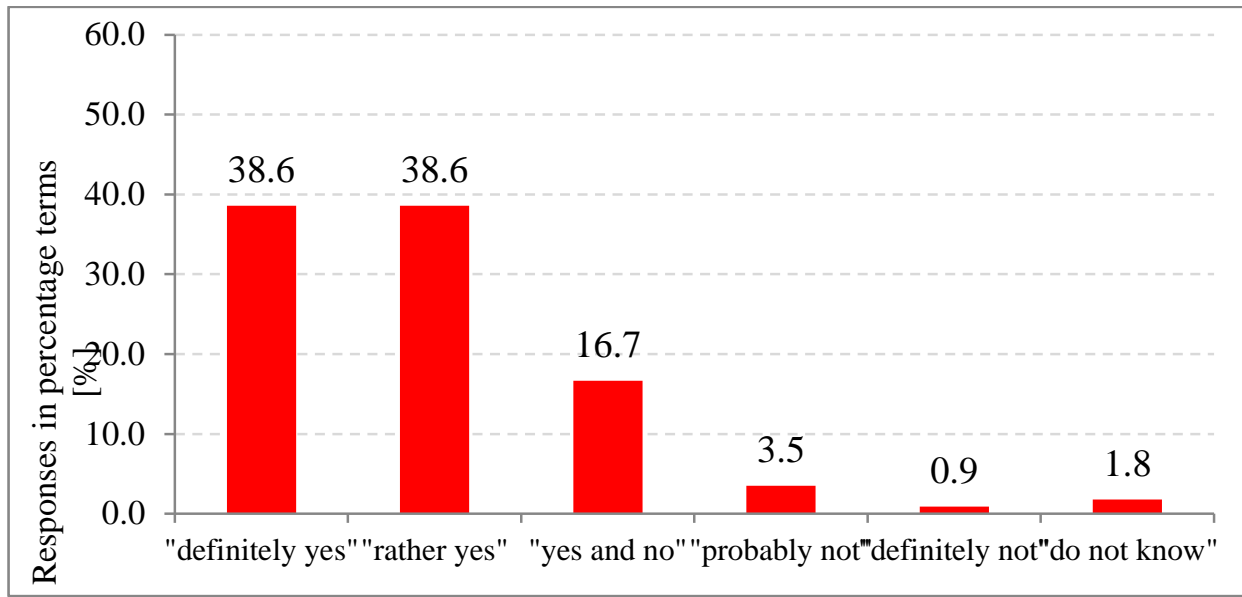

Fig. 5: Distribution of Answers to the Question "Is the Progressive Extension of the Scope of Electronic Communication between Accounting Offices and Clients a Beneficial Phenomenon from Your Perspective, Facilitating the Running of Your Business?" Source: Own Study

With 95-percent probability, it can be stated that confidence interval $[69.5 \% ; 84.9 \%]$ will cover the percentage of people considering the progressive extension of the scope of electronic communication between accounting offices and clients as a positive phenomenon, within the population of the accountancy offices' employees.

In order to increase the reliability of the results (to reduce the maximum value of statistical error of response percentages), enlarging the study sample would be justifiable. However, as already mentioned, these studies relate to a relatively narrow group of specialists - and enlarging the study sample will not be easy.

\section{Conclusions and further research}

Accounting is the language of business and like every language has to follow changes in the surrounding environment. In various stages of accounting development, lots of its aspects have evolved. The cause of these changes lies scientific, technical, economic and organizational progress. Economic, territorial, social and cultural changes are important as well (Sawicki 2013). Currently, there are visible trends in the virtualization of the information flow. As is clear from research, accounting information flow accounting increasingly carried out through the Internet.

Taking into consideration the data collected and conducted analyses, it can be clearly stated that, in the opinion of specialists in the field of accounting virtualization of the information flow can be positively evaluated. Also, vision of further changes in this area is positively accepted by the respondents. There is a general awareness of the potential benefits posed by the analyzed phenomenon. It is worth to note that specialists who undergo research can therefore act as spokespersons to encourage further virtualization of subsequent areas of information flow in companies they service. Clients of accounting offices do not always fully understand the logic behind the introduction of new (perhaps requiring additional investments or new skills) standards in the area of contact with government authorities. Given a specific period of time (over the next two years) the potential comes visible as well as the willingness of those concerned to make the extra effort to implement the next, even more advanced, complex solutions. This creates a positive atmosphere for these solutions to go into effect smoothly and effectively. The phenomenon of natural resistance to any change, well known in management, in this case should have very little significance. It should be emphasized that all these observations are confirmed not only in the sphere of not only mandatory, but also voluntary operations of the respondents. Even among the small group of respondents - who have expressed other than clearly positive assessment - indecisiveness towards changes dominated over rejecting them all together? For each question, negative evaluations constituted only $3 \%$ to $4 \%$ of all opinions. In this situation, it should be noted that the scale of virtualization of the information flow and the scope of changes are received positively and further prospects of this process also look favorable.

The authors believe that the presented subject matter needs to be continued in the form of in-depth studies that would expand the available knowledge about the prospects for further development of the information flow virtualization process where the private and public sector meet. In particular, an analysis of the evolution of formal and legal conditions and their impact and appropriateness towards the changes taking place in the area of improvement of ICT systems should be analyzed. An equally important issue that requires a wider examination is the deepening phenomenon of outsourcing accounting services in light of new challenges which are a consequence of dynamic processes identified in this article.

\section{References}

[1] Alford A, Jones J, Leftwich R., Zmijewski M (1993) the relative informativeness of accounting disclosures in different countries. Journal of Accounting Research, 183-223. http://dx.doi.org/10.2307/2491170.

[2] Baran M (2008) Informacja $z$ perspektywy nauki organizacji i zarządzania. [in:] (Kiełtyka L ed.) Technologie i systemy komunikacji oraz zarządzania informacją i wiedzą, Warszawa: DIFIN, pp. 211-217.

[3] Bauer K (2009) Zarządzanie informacjami w procesie upadłościowo naprawczym przedsiębiorstw, Wydawnictwo Uniwersytetu Jagiellońskiego, Kraków. 
[4] Budzanowska-Drzewiecka M (2012) E-consumer Behaviour as the Basis for Promotional Activities on the Internet In Management Dilemmas in the Information Technology Era (Sołek C ed.), Wydawnictwo Wojskowej Akademii Technicznej, Warszawa, pp. 130-141.

[5] Bushman RM, Smith AJ (2001) financial accounting information and corporate governance. Journal of accounting and Economics, 32(1), 237-333 http://dx.doi.org/10.1016/S0165-4101(01)00027-1.

[6] Bushman RM., Piotroski JD (2006) financial reporting incentives for conservative accounting: The influence of legal and political institutions. Journal of Accounting and Economics, 42(1), 107-148 http://dx.doi.org/10.1016/j.jacceco.2005.10.005.

[7] Buthelezi M, Adigun MO, Ekabua OO, \& Iyilade J (2008) Accounting, Pricing and Charging Service Models for a GUISET Grid-Based Service Provisioning Environment. In CSREA EEE, pp. 350-355.

[8] Chen CJ, Chen S, Su X (2001) is accounting information valuerelevant in the emerging Chinese stock market? Journal of International Accounting, Auditing and Taxation, 10(1), 1-22. http://dx.doi.org/10.1016/S1061-9518(01)00033-7.

[9] Chojnacka A (2007) Organizacja obiegu dokumentów księgowych a operacyjne zarządzanie przedsiębiorstwem, Prace Naukowe Akademii Ekonomicznej we Wrocławiu, Nr 1150, Informatyka Ekonomiczna 10, 297-305.

[10]Chomiak-Orsa I (2007) Wykorzystanie nowoczesnych technologii w doskonaleniu procesów controllingowych, Prace Naukowe Akademii Ekonomicznej we Wrocławiu, Nr 1150, Informatyka Ekonomiczna 10 95-104.

[11]Dziekoński K (2011) Projekty w innowacyjnych małych i średnich przedsiębiorstwach, Ekonomia i Zarządzanie 3 (4), 125-134.

[12]Dziembek D, Stępniak C (2003) Możliwości zastosowania wirtualnego outsourcingu $\mathrm{w}$ małych przedsiębiorstwach, Acta Universitatis Lodziensis, Folia Oeconomica 167, 359-372.

[13]Gierusz J (2015) Dylematy harmonizacji rachunkowości. Zeszyty Teoretyczne Rachunkowości, (82), 19-38 (DOI 10.5604/16414381.1155807).

[14]Jiang M, Novales CDC, Mathieu G, Casson J, Rogers W, \& Gordon J (2011) an apel tool based cpu usage accounting infrastructure for large scale computing grids. In Data Driven e-Science, Springer New York, pp. 175-186. http://dx.doi.org/10.1007/978-1-4419-8014-4_14.

[15]Kelly K (1999) New rules for the new economy, Penguin.

[16]Krasodomska J (2010) Anglosaski i kontynentalny model rachunkowości na przykładzie wybranych krajów. Zeszyty Teoretyczne Rachunkowości, (55), 119-138.

[17] Łasak P (2009) Wpływ asymetrii informacji na finansowanie przedsiębiorstw krajów wschodzących w dobie globalnego kryzysu wybrane aspekty, Zeszyty Naukowe Wyższej Szkoły Zarządzania Finansów we Wrocławiu, Wrocław.

[18]Leuz C, Wüstemann J (2003) the role of accounting in the German financial system, http://papers.ssrn.com/sol3/papers.cfm?abstract_id=427000 (accessed 10 July 2015).

[19]Lipińska A (2012) Knowledge Management of Companies in the information Society. Theory and Practice In Management Dilemmas in the Information Technology Era (Sołek C ed.), Wydawnictwo Wojskowej Akademii Technicznej, Warszawa.

[20]Matejun M (2010) Outsourcing rachunkowości i doradztwa podatkowego w sektorze MŚP-implikacje dla urzędników skarbowych. In Problemy i wyzwania w zarządzaniu organizacjami publicznymi (Adamik A, Matejun M, Zakrzewska-Bielawska A ed.). Wydawnictwo Politechniki Łódzkiej, Łódź, pp. 276-299.

[21]Micherda B, Świetla K (2014) Współczesna rachunkowość w świetle badań empirycznych. Difin.Warszawa.

[22]Okoń-Horodyńska E, Wisła R, Sierotowicz T (2013) Leading Trends of the Information Society Technology Development, Transformation in Business \& Economics, vol. 12, no 2B (29B).

[23] Parsons LM (2003) Is accounting information from nonprofit organizations useful to donors? A review of charitable giving and valuerelevance. Journal of Accounting Literature, 22, 104-129.

[24]Reetz J, Soddemann T, Heupers B, \& Wolfrat J (2007) Accounting Facilities in the European Supercomputing Grid DEISA. In German eScience Conference. Available at: http://www.ges2007.de (accessed 10 July 2015).

[25]Rokita S, Kaszuba-Perz A (2012) Determinants of construction of information system which supports management of innovations, in eFinanse, Wydawnictwo Wyższej Szkoły Informatyki i Zarządzania w Rzeszowie, vol. 8, pp.53-63.

[26]Sawicki K (2013). Zakres rachunkowości jako nauki. Zeszyty Teoretyczne Rachunkowości, (71), 211-226. http://dx.doi.org/10.5604/16414381.1061657.
[27]Sierotowicz T (2013) Koncepcje modeli biznesowych organizacji działających w wirtualnej przestrzeni życia gospodarczego, Zarzadzanie i Finanse, nr 1, vol. 4.

[28]Strojny J, Żmuda M (2005) Wybrane determinanty kształtujące potencjał marketingowy i internetowy, In Internet a zarządzanie marketingowe (Ślusarczyk S, Góra R, Strojny J ed.), WSzliZ, Rzeszów, pp. 125-156.

[29]Surdykowska S.T. (1999), Rachunkowość międzynarodowa, Zakamycze.

[30] Świetla K (2014) Outsourcing usług księgowych w świetle oczekiwań biur rachunkowych i ich klientów, Wydawnictwo Uniwersytetu Ekonomicznego w Krakowie, Kraków.

[31]Szymczyk-Madej K (2014) Budowa i funkcjonowanie systemów informatycznych rachunkowości-porównanie wyników badań z lat 2005 i 2014. Prace Naukowe Uniwersytetu Ekonomicznego we Wrocławiu. 344 Rachunkowość a controlling. 520-530. http://dx.doi.org/10.15611/pn.2014.344.48.

[32] Tadeusiewicz R (2002) Społeczność Internetu. Akademicka Oficyna Wydawnicza EXIT. Warszawa.

[33]Urbanowska-Sojkin E, Banaszyk P (2009) Ewolucja przedsiębiorstw w Polsce w okresie transformacji gospodarki po 1989 roku. Ruch prawniczy, socjologiczny i ekonomiczny, LXXI, 2, 321-346.

[34] Waldburger M, Göhner M, Reiser, H, Rodosek GD \& Stiller B (2009) Evaluation of an Accounting Model for Dynamic Virtual Organizations. Journal of Grid Computing, 7(2), 181-204 http://dx.doi.org/10.1007/s10723-008-9109-9. 